\title{
ANALISIS LEARNING OBSTACLE SISWA DALAM PEMBELAJARAN ILMU PENGETAHUAN SOSIAL DI KELAS IV SD
}

\section{THE ANALYSIS OF THE STUDENTS' OBSTACLES IN LEARNING SOCIAL SCIENCE OF THE $4^{\text {TH }}$ GRADE PRIMARY SCHOOL}

\author{
Tara Dika Utama ${ }^{1}$, M. Japar ${ }^{2}$ \\ ${ }^{1,2}$ Pascasarjana Pendidkan Dasar Universitas Negeri Jakarta \\ E-mail: taradikautama@gmail.com ${ }^{1}$, japar@gmail.com ${ }^{2}$
}

\begin{abstract}
Abstrak
Pembelajaran Ilmu Pengetahuan Sosial merupakan salah satu pembelajaran yang dipelajari di SD. Dalam materi pahlawan, memungkinkan terdapat hambatan yang akan ditemukan oleh siswa. Rumusan masalah dalam penelitian ini adalah untuk mengetahui bagaimana learning obstacle yang dihadapi siswa. Tujuan dari penelitian ini untuk menganalisis learning obstacle yang ditemukan siswa dalam materi pahlawan. Penelitian ini menggunakan metode analisis kualitatif deskriptif. Instrumen yang digunakan dalam penelitian ini berupa wawancara dan tes. Subjek dalam penelitian ini adalah siswa kelas IV SD Negeri Rawamangun 05. Berdasarkan hasil penelitian, diperoleh 3 tipe learning obstacle, tipe 1 siswa mengalami kesulitan dalam menunjukkan letak daerah kerajaan, tipe 2 siswa mengalami kesulitan dalam menentukan asal kerajaan dari beberapa raja, tipe 3 siswa belum bisa menunjukkan waktu berdirinya sebuah kerajaan. Hasil penelitian yang dipaparkan oleh peneliti ini akan digunakan pada penelitian lebih lanjut.
\end{abstract}

Kata Kunci: Learning Obstacle, Ilmu Pengetahuan Sosial, Pahlawan

\begin{abstract}
Social science is one of the lessons learned in the primary school. One of the materials of this subject is national heroes where the students find out difficulties in learning it. The problem of this research was the learning obstacles faced by the students. The purpose of this study was to analyze the learning obstacles the students faced in national heroes material. This research used descriptive qualiative analysis method. Instrument techniques used in this study were interviews and test. The subjects in this study were the $4^{\text {th }}$ grade students of primary school. The results of the research obtained three types of learning obstacles, first type was the students had difficulties in showing the location of the kingdom area, the second type was difficulties in determining the original kingdom of several kings, the third was unable in determining an empire established. The result of the research presented by the researcher is expected to be used for further research.
\end{abstract}

Keywords: Learning Obstacle, Social Science Learning, National Hero

\section{Pendahuluan}

Belajar adalah suatu usaha yang dilakukan secara sadar oleh seseorang atau individu dengan tujuan untuk meningkatkan kemampuan diri atau perubahan terhadap diri melalui serangkaian latihan-latihan dan pengulangan-pengulangan. Belajar juga dapat diartikan sebagai sebuah proses dimana seseorang atau individu mengalami perubahan perilaku sebagai akibat dari sebuah pengalaman (Susanto, 2013: 1). 
Kurikulum pendidikan dasar pada dasarnya meliputi sejumlah bahan kajian atau mata pelajaran. Salah satu diantaranya adalah mata pelajaran Ilmu Pengetahuan Sosial (IPS). Mata pelajaran IPS adalah mata pelajaran yang mempelajari seperangkat peristiwa fakta, konsep, dan generalisasi yang berhubungan dengan isu sosial. Pembelajaran IPS di sekolah dasar tidak bersifat keilmuan, tetapi bersifat pengetahuan dan praktek atau penerapan dimana bahan yang diajarkan bukan teori-teori sosial atau ilmu sosial melainkan hal praktis dan mudah dipahami agar berguna bagi diri siswa di lingkungannya. Sehingga setelah mempelajari mata pelajaran IPS, diharapkan peserta didik dapat menjadi warga negara yang bertanggung jawab, demoktratis dan cinta damai selain itu siswa bisa mendapatkan hasil belajar yang memenuhi KKM (Kriteria Ketuntasan Minimal).

Dalam sistem pendidikan nasional rumusan tujuan pendidikan, baik tujuan kurikuler maupun tujuan instruksional, menggunakan klasifikasi hasil belajar dari Benyamin Bloom yang secara garis besar membaginya menjadi tiga ranah, yaitu ranah kognitif, ranah afektif, dan ranah psikomotoris.

Ranah kognitif berkenaan dengan hasil belajar intelektual yang terdiri dari enam aspek, yakni pengetahuan atau ingatan, pemahaman, aplikasi, analisis, sintesis, dan evaluasi. Ranah kognitif biasanya digunakan untuk mengukur keberhasilan siswa di bidang akademik dan dijadikan panduan bagi guru untuk menetapkan tingkat keberhasilan siswa.

Ranah afektif berkenaan dengan sikap yang terdiri dari lima aspek, yakni penerimaan, jawaban atau reaksi, penilaian, organisasi, dan internalisasi. Ranah psikomotoris berkenaan dengan hasil belajar keterampilan dan kemampuan bertindak. Ranah afektif berkaitan erat dengan penanaman karakter pada diri siswa. Oleh karena itu, dalam pembelajaran terdapat tujuan instruksional yang harus berkenaan dengan pengembangan karakter siswa, baik selama pembelajaran maupun sikap yang diharapkan muncul sehingga dapat diaplikasikan dalam, kehidupan sehari-hari.

Ranah psikomotor berkenaan dengan keterampilan motorik anak. Ada enam aspek ranah psikomotoris, yakni gerakan refleks, keterampilan gerakan dasar, kemampuan perseptual, keharmonisan atau ketepatan, gerakan keterampilan kompleks, dan gerakan ekspresif dan interpretatif. Keterampilan psikomotorik dapat diamati selama siswa mengikuti proses pembelajaran.

Di antara ketiga ranah itu, ranah kognitif yang banyak dinilai oleh para guru di sekolah karena berkaitan dengan kemampuan para siswa dalam menguasai isi bahan pelajaran, termasuk pada pelajaran Bahasa Indonesia. Penilaian ini dapat tergolong ke dalam penilaian secara formatif maupun sumatif.

Sejalan dengan pendapat Sudjana, Sardiman (2011: 28) mengatakan hasil belajar meliputi: “(a) Hal ihwal keilmuan dan pengetahuan, konsep atau fakta (kognitif); (b) Hal ihwal personal, kepribadian atau sikap (afektif); (c) Hal ihwal kelakuan, keterampilan atau penampilan (psikomotorik)".

Menurut Slameto (2010: 138) hasil belajar dalam kecakapan kognitif itu mempunyai hierarki bertingkat-tingkat. Adapun tingkat-tingkat yang dimaksud adalah: (a) Informasi non verbal; (b) Materi pahlawan bila dibandingkan dengan materi lainnya yang terdapat dalam Ilmu Pengetahuan Sosial merupakan materi yang cukup sulit untuk dipahami. Rendahnya penguasaan siswa terhadap materi tersebut dapat disebabkan oleh faktor yang berasal dari dalam diri siswa (faktor internal) dan faktor yang berasal dari lingkungan luar siswa (faktor eksternal). Kesulitan yang dihadapi siswa dalam materi geometri tersebut harus bisa diatasi oleh seorang guru, agar tujuan dari materi geometri 
tersebut dapat diterima oleh siswa secara menyeluruh.

Kesulitan yang dihadapi oleh siswa dalam materi pahlawan ini bisa disebut dengan hambatan (learning obstacle) (Yusuf, R., \& W., 2017). Menurut Suryadi dalam Unaenah (2017: 290) "terdapat tiga jenis learning obstacles, yaitu ontogenical obstacle, didactical obstacle, dan epistemological obstacle". Hambatan yang diperoleh siswa bisa saja disebabkan oleh faktor internal atau faktor eksternal yang menyebabkan siswa mengalami hambatan dalam menerima atau menyerap materi pahlawan. Maka dari itu seorang guru harus mampu memberikan penjelasan yang mudah dipahami oleh siswa (Ashsiddiqi, 2012) dan membiasakan para siswa untuk belajar mencari sendiri yang tujuannya agar siswa bisa menggali informasi sebanyak-banyaknya serta secara tidak langsung akan membuat siswa untuk berpikir kritis (Suprihatin, 2015). Dalam pembelajaran ilmu pengetahuan sosial siswa dituntut untuk berpikir secara kritis, berpikir kritis tersebut harus sudah ditanamkan kepada siswa baik dari siswa kelas I SD sampai siswa kelas VI SD dengan tingkatan berpikir kritis yang paling dasar sampai ke yang paling tinggi. Hal tersebut sejalan dengan pendapat Siswono dalam Fatmawati, Mardiyana, \& Triyanto (2014: 912-913) yang menyatakan bahwa tingkatan berpikir sampai berpikir kritis yaitu "tingkat berpikir paling rendah (TBK 0) adalah keterampilan menghafal (recall thinking), Tingkat berpikir selanjutnya adalah keterampilan dasar (basic thinking) atau TBK 1, berpikir tingkat tinggi adalah kemampuan berpikir kritis (TBK 2 dan TBK 3)". Tingkatan berpikir tersebut harus mampu siswa kuasai agar pembelajaran Matematika lebih berkualitas dan siswa juga bisa menangani learning obstacle yang ditemukan dalam setiap materi matematika.

\section{Metode penelitian}

Subjek pada penelitian ini adalah responden yang akan menyelesaikan soal yang diberikan peneliti, yaitu siswa yang sudah mendapatkan materi pelajaran tentang pahlawan. Subjek dalam penelitian ini adalah siswa kelas IV SD Negeri Rawamangun 05 sebanyak 31 orang. Dalam melakukan penelitian ini teknik sampling yang digunakan yaitu nonprobability sampling dengan teknik purposive sampling. Menurut Sugiyono (2016: 85) purposive sampling adalah teknik pengambilan sampel sumber data dengan pertimbangan tertentu.

Metode penelitian yang digunakan dalam artikel penelitian ini menggunakan metode kualitatif deksriptif. Metode penelitian kualitatif digunakan untuk mendapatkan data yang mendalam, suatu data yang mengandung makna. Oleh karena itu, penelitian kualitatif lebih menekankan makna daripada generalisasi (Sugiyono, 2014: 15). Instrumen penelitian disesuaikan dengan teknik pengumpulan data yang dipakai. Teknik pengumpulan data dalam penelitian ini adalah lembar wawancara dan tes (lembar soal). Dalam penelitian ini, peneliti melakukan wawancara langsung dengan guru kelas IV SD yang tujuannya untuk mengetahui learning obstacle yang ditemukan dalam materi pahlawan. Serta peneliti juga melalukan tes soal kepada siswa kelas IV yang tujuannya untuk mengetahui macam-macam tipe learning obstacle yang ditemukan siswa dalam materi pahlawan. Data yang dianalisis dalam penelitian ini berbentuk deskriptif, yaitu hasil pengumpulan data melalui instrumen yang dianalisis dan disajikan dalam bentuk deskriptif. 


\section{Hasil dan pembahasan}

\subsection{Hasil}

Berdasarkan hasil observasi lapangan yang dilakukan oleh peneliti pada tanggal 05 November 2018 yang bertempat di sekolah dasar negeri yang berlokasi di daerah Rawamangun, terdapat 3 tipe learning obstacle yang ditemukan, yaitu learning obstacle tipe 1 bererkaitan dengan menunjukkan letak daerah kerajaan. Siswa mengalami kesulitan dalam menunjukkan letak daerah kerajaan. Berdasarkan hasil penelitian tersebut terdapat 20 siswa masih keliru dalam menunjukkan letak daerah kerajaan Tarumanegara. Serta berdasarkan tipe 1 tersebut ada 11 siswa yang sudah bisa menunjukkan letak daerah kerajaan Tarumanegara.

Learning obstacle tipe 2 terkait dengan kesulitan dalam menentukan asal kerajaan dari beberapa raja. Siswa mengalami kesulitan dalam menentukan asal kerajaan dari beberapa raja. Berdasarkan hasil penelitian pada soal no 12 sebanyak 17 siswa sudah bisa menunjukkan masa pemerintahan raja Purnawarman asal kerajaan dari beberapa raja. Sedangkan di soal no 2 sebanyak 14 siswa masih keliru dalam menentukan asal kerajaan dari beberapa raja.

Learning obstacle tipe 3 terkait kemampuan siswa dalam menunjukkan waktu berdirinya sebuah kerajaan. Terdapat beberapa siswa yang sudah bisa menunjukkan waktu berdirinya sebuah kerajaan, tetapi ada juga beberapa siswa yang masih belum bisa menunjukkan waktu berdirinya sebuah kerajaan. Hal tersebut dapat dilihat dari hasil penelitian yang menunjukkan bahwa terdapat 21 siswa sudah bisa menjawab dengan benar waktu berdirinya kerajaan Kutai. Hasil penelitian yang dipaparkan oleh peneliti ini akan digunakan pada penelitian lebih lanjut.

\subsection{Pembahasan}

Berdasarkan hasil wawancara dengan guru serta tes yang diberikan kepada siswa kelas IV SD Negeri Rawamangun 05 terdapat beberapa faktor yang mempengaruhi siswa mengalami learning obstacle. Faktor-faktor tersebut kemudian dikategorikan ke dalam faktor internal dan faktor eksternal.

\subsubsection{Faktor internal}

Beberapa faktor internal yang mempengaruhi learning obstacle ilmu pengetahuan sosial antara lain sikap dalam belajar IPS. Sikap positif terhadap suatu pembelajaran adalah awal yang baik untuk proses pembelajaran selanjutnya. Sebaliknya sikap negatif akan berpotensi menimbulkan learning obstacle atau memberikan hasil belajar yang kurang maksimal. Beberapa orang siswa menyatakan tidak menyukai materi tentang pahlawan. Hal ini memberikan persepsi negatif terhadap pembelajaran IPS. Siswa menganggap materi tersebut adalah materi yang sulit. Mereka juga tidak antusias menerima materi yang disampaikan. Selain itu juga mengakibatkan rendahnya minat dan motivasi siswa dalam belajar IPS. Siswa juga tidak aktif mengikuti pembelajaran IPS yang diberikan oleh guru. Siswa seringkali tidak memperhatikan guru ketika guru menjelaskan materi, masih mengobrol dengan teman sebelahnya atau sibuk sendiri. Kemudian faktor fisiologis yakni kesehatan fisik siswa yang berdampak pada kurangnya konsentrasi belajar dan mengantuk. Ketika kondisi fisik tidak dalam keadaan optimal siswa tidak bisa menangkap materi yang disampaikan dengan baik.

\subsubsection{Faktor Eksternal}

Berdasarkan hasil wawancara terhadap siswa, salah satu faktor eksternal siswa learning obstacle adalah berasal dari keluarga. Keluarga belum mendukung aktivitas 
belajar secara optimal yang ditandai dengan kurangnya latihan atau mengulang pelajaran di rumah atau tidak mengikutsertakan siswa pada jam belajar tambahan. Faktor eksternal yang lain adalah pada metode atau strategi pembelajaran yang digunakan oleh guru untuk menyampaikan materi ini. Kebanyakan guru menyampaikan materi pahlawan menggunakan ceramah, padahal siswa membutuhkan pendekatan yang berbeda agar bisa memahami pembelajaran secara optimal.

\section{Kesimpulan}

Berdasarkan uraian di atas dapat disimpulkan bahwa terdapat beberapa siswa yang mengalami learning obstacle dalam 3 tipe yang disebutkan, yaitu: tipe 1 siswa mengalami kesulitan dalam menunjukkan letak daerah kerajaan, tipe 2 siswa mengalami kesulitan dalam menentukan asal kerajaan dari beberapa raja, tipe 3 siswa belum bisa menunjukkan waktu berdirinya sebuah kerajaan serta terdapat pula faktor internal dan faktor eksternal yang mempengaruhi hasil belajar siswa.

\section{Daftar Pustaka}

Ashsiddiqi, H. (2012). Kompetensi Sosial Guru dalam Pembelajaran dan Pengembangannya. Ta'dib, 17(12), 61-67. Retrieved from http://jurnal.radenfatah.ac.id/index.php/tadib/article/view/25

Fatmawati, H., Mardiyana, \& Triyanto. (2014). Analisis Berpikir Kritis Siswa dalam Pemecahan Masalah Matematika Berdasarkan Polya pada Pokok Bahasan Persamaan Kuadrat (Penelitian pada Siswa Kelas X Smk Muhammadiyah 1 Sragen Tahun Pelajaran 2013/2014). Jurnal: Elektronik Pembelajaran Matematika, 2(9), 911-922.Retrieved from http://jurnal.fkip.uns.ac.id/index.php/s2math/article/view/4830

Sardiman, A. M. (2011). Interaksi dan Motivasi Belajar Mengajar. Jakarta: Rajawali Press.

Slameto. (2010). Belajar dan Faktor-Faktor yang Mempengaruhinya. Jakarta: Rineka Cipta.

Sugiyono. (2014). Metode Penelitian Pendidikan: Pendekatan Kualitatif, $R \& D$. Bandung: Alfabeta.

Sugiyono. (2016). Metode Penelitian Kuantitatif, Kualitatif dan R\&D. Bandung: Alfabeta.

Suprihatin, S. (2015). Upaya Guru dalam Meningkatkan Motivasi Belajar Siswa. Pomosi, 3(1), 73-82. https://doi.org/siti suprihatin

Susanto, A. (2013). Teori Belajar Pembelajaran di Sekolah Dasar. Jakarta: Kencana Prenadamedia Group.

Unaenah, E. (2017). Analisis Learning Obstacles Konsep Geometri pada Mahasiswa Semester 1 Program Studi Pendidikan Dosen Sekolah Dasar. Prosiding Seminar Nasional Pendidikan FKIP UNTIRTA, 289-296. Retrieved from http://jurnal.untirta.ac.id/index.php/psnp/article/view/289-296

Yusuf, Y., R., N. T., \& W., T. Y. (2017). Analisis Hambatan Belajar (Learning Obstacle) Siswa SMP pada Materi Statistika. Aksioma, 8(1), 73-82. Retrieved from https://media.neliti.com/media/publications/176775-ID-analisis-hambatan-belajarlearning-obsta.pdf 